\title{
Marketing support of decision-making at the forest enterprise: A case study on roundwood assortments portfolio
}

\author{
Daniel Halaj \\ Technical University in Zvolen, Faculty of Forestry, T. G. Masaryka 24, 96001 Zvolen, Slovak Republic
}

\begin{abstract}
This paper focuses on the marketing support of decision-making at the forest enterprise on the example of forestry products, concretely, of roundwood assortments on the chosen state forest enterprise in the Slovak Republic. The most used marketing decision-making models as SWOT, BCG, and GE matrices with support of ABC analysis were used for chosen research purpose. Additionally, these models were compared to confirm their reliability and expressing power for marketing management of forest enterprise. The conclusions confirm that the use of these models build a strong framework for the decision-making support of forest enterprise management. The outcomes of models contribute to each other and they do not contradict. However, it is necessary to have a strong base of forestry practice knowledge due to the correct interpretation of these models. In contrast to other industrial companies, forest sector is a very specific regarding the long rotation and payback period. The main pillar of the product portfolio and forest enterprise either are assortments of the III. qualitative class and broadleaf pulpwood with the $86 \%$ share on total revenues. Concerning the prevalence of threats and company strengths, it is necessary to choose diversification management approach for the product portfolio.
\end{abstract}

Key words: decision-making; marketing; models; forest enterprise; strategic management

Editor: Miloš Pánek

\section{Introduction}

Trade with roundwood is the most important source of income for preserving the functions of forests and maintenance of the employment in the forestry sector. More than $80 \%$ of the revenues of forest enterprises are provided by the sale of roundwood in the Slovak Republic (Ministry of Agriculture and Rural Development of the Slovak Republic 2018). Besides of the forest sector, wood is the main raw material also for the wood-processing industry therethrough the employment, revenues and profits are provided also in this area of the Slovak economy as well (Kaputa et al. 2016; Parobek et al. 2014; Paluš et al. 2015, 2018). In generally, global but also regional demand on wood consumption for the power, construction, and furniture industry will furthest raise (FAO 2018; Jochem et al. 2016; Herrera 2018). According the FAO (2018), the main factors affecting long-term global demand for wood products include: i) increase of the world's population, ii) continued economic growth, iii) the rapid growth of developing economies, iv) the environmental policies and regulations inducing decline in harvesting from natural forests and the emergence of planted forests as the major source of wood supply and v) the energy policies with the emphasis on the use of forest biomass.

Therefore, from these objective results it comes out a great opportunity to realize marketing approaches just in the area of selling wood (Elyakime \& Cabanettes 2009; Lovrić et al. 2018; Rönnqvist et al. 2018), and non-wood forest products on the market (Ludvig et al. 2016; Šišák et al. 2016; Huber et al. 2017; Neis et al. 2019) and to evaluate and market the extra benefits of forests also known as non-productive functions of forests (Sarvašová et al. 2014; Sarvašová \& Dobšinská 2016). However, the use of marketing management in forestry is of less interest of research agenda, what also results from the low level of publicized scientific works with the application of marketing principles in this sector (Ok 2005; Greppel et al. 2009). Additionally, the range of marketing in the forest management is low. In other words, it has been not enough space dedicated to it (Brodrechtova 2008).

The forest enterprises stay as a producer of roundwood at the end of the chain of derived demand on wood (Cooper 1990; Chirinko \& Mallick 2011; Knauf 2015). The fast-varying conditions on the markets with the

*Corresponding author. Daniel Halaj, e-mail: halaj@tuzvo.sk, phone: +421455206320 
consumer goods affect indirectly the forest enterprise by change of their customers' wants and needs. This situation requires strategic oriented marketing (Hansen \& Juslin 2011). The forest enterprise could on one side rapid and flexible react on the market variations, on the other side, use the opportunities on the rising markets (Owari et al. 2006; Kim et al. 2018).

The application of decision-making models in marketing management of forest enterprises is very rare despite of their high expressing power for management process and especially the possibility to assess the product or customers' portfolio (Halaj et al. 2018). They are used more in other sectors of national economy, e.g. food industry (Seggie 2007; Torquati 2018) or to evaluate the investment funds or financial statement on the capital markets (Haltofová \& Štěpánková 2014; Chen et al. 2015).

This case study was carried out on the selected state forest enterprise in the Slovak Republic. It applied methods of decision-making models on product portfolio of broadleaf and coniferous roundwood assortments.

The aim of the paper was to point out of the significant marketing role in the forest enterprise management, to stress the use of decision-making models on the specific example of forestry products and to compare selected models according the chosen indicators.

\section{Material and methods}

The selected state forest enterprise operates on the forest area of 52094 ha, with the forest cover $40.5 \%$, and the share of coniferous with $29 \%$ and broadleaf forest $71 \%$. The annual amount of harvested roundwood is in the range of $185000-200000 \mathrm{~m}^{3}$ with the average annual revenues in amount of 8.3 million $€$ (2017). The necessary secondary data were taken from the report of the company management, concretely from the profit and loss statement. For the research purpose, the data about revenues for individual broadleaf and coniferous roundwood assortments were analysed for the period of 2016 - 2017. There had to be also primary data needed for one of the decision-making models (GE matrix) in form of subjective opinions of experts.

This paper was focused on the use of marketing decision-making models for the evaluation of the product portfolio by reason of the management of forests production function. Therefore, the portfolio analysis of the roundwood assortments was carried out by the SWOT analysis - the SWOT, Opportunity and Threat matrices (Samejima et al. 2006; Kajanus et al. 2012; Kotler \& Keller 2015), BCG Growth-Share matrix (Meffert et al. 2014; Kotler \& Keller 2015), the Mckinsey GE matrix (Baran 2007; Baum 2012) and ABC analysis also called the curve of the turnover concentration (Jacobs et al. 2010; Wild 2017) in the selected forest enterprise. These models were chosen by reason of their generality and the highest rate of utilization in managerial practice.

\subsection{SWOT analysis}

The SWOT analysis as a decision-making model was chosen for the evaluation of the strengths and weaknesses of the given product portfolio and also for the opportunities and threats on the market with the roundwood assortments. The SWOT, opportunity and threat matrices are as a results of the evaluation process. At the same time, the matrices offer the proposal of the marketing strategy for the product portfolio or present the marketing decision-making support.

The SWOT indicators were identified by forest enterprise management. They were subsequently assessed in two way methodological approaches.

First, the company management evaluated the indicators regarding their strengths or weaknesses by Likert scale from the strongest (2) to the weakest (-2). Afterwards, the seriousness was bind to each indicator in the scale from the low (1) to the highest (3). The indicator could reach by multiplying of both values the maximum positive value of 6 (means strength or opportunity) or the maximum negative value -6 (weakness or threat). The evaluations of all four company managers were averaged and so the two values (difference between strengths and weaknesses and opportunities and threats) giving the point coordinates (axis $\mathrm{x}$ and $\mathrm{y}$ ) were obtained (Fig. 1). The searched point could lie in one of the four quadrants where each of them presents concrete marketing strategy proposal.

Second, the strengths and weaknesses were also evaluated by Likert scale from the strongest (5) to the weakest (1) and to them pertaining seriousness from the low (1) to the highest (3). The final pair of values for each indicator defines coordinates of points in related SWOT matrix (Fig. 2). By opportunity and threat matrix (Fig. $3-4$ ), the probability of occurrence and success (axis $\mathrm{x}$ ) were assessed by Likert scale within the threats from the biggest risk (1) to lower risk (2) and within the opportunities from average success (3) to biggest chance (5). The seriousness of indicators was divided into seriousness of risks and chances at the same scale from 1 to 3 . The coordinates of points in the opportunity and threat matrices were calculated at the same manner as in the SWOT matrix.

\subsection{BCG matrix}

The design of the BCG matrix is based on the two parameters, namely the relative share of SBUs (Strategic Business units) on the total revenues and the rate of the revenues growth, or growth index. The relative share on the total revenues is described by following formula:

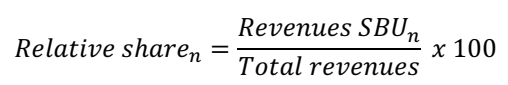


where

relative share ${ }_{n}$ is the share of $\mathrm{n}$-product on the total revenues [\%],

revenues $S B U_{n}$ are revenues of n-product $\left(\mathrm{SBU}_{\mathrm{n}}\right)$ in the current period,

total revenues are revenues of all products (SBU) in the current period.

The growth index of the revenues $\left(i_{n}\right)$ is the ratio indicator measured by relation of the n-product $\left(S B U_{n}\right)$ revenues in the current year to revenues in the previous one:

$$
i_{n}=\frac{\text { Revenues } S B U_{n \text { current year }}}{\text { Revenues } S B U_{n \text { previous year }}}
$$

The relative share of revenues introduces the horizontal axis (x) in the BCG matrix. The median value of the achieved shares of SBUs in total revenues signifies a limit between high and low relative shares. The vertical axis (y) represents the growth index of revenues, where value 1 is considered as the limit between high and low growth index. Based on the limit values of the relative revenues share and revenues growth index, the BCG matrix is divided into four quadrants: cash cows, dogs, question marks and stars. In general, all SBUs situated in the quadrants cash cows and stars achieve positive cash flow and they are perspective for the enterprise. On the other hand, the SBUs placed in the quadrants question marks and dogs require significant investment and may reach low profits or even losses (Evans \& Berman 1990).

\subsection{GE matrix}

The GE matrix is one of the decision-making models which balances some limitations of the BCG matrix for more investigated factors in two main dimensions (Baran 2007; Baum 2012): competitive position (axis $\mathrm{x}$ ) and market attractiveness (axis y) of the selected products, or services (SBU). In this case, the competitive position covered following nine factors: i) relative market share, ii) distribution channels, iii) product quality, iv) product trademark and image, v) costs, vi) relative profit, vii) production effectiveness, viii) product promotion and ix) innovation abilities. The market attractiveness consisted from these specific nine factors: i) market capacity, ii) rate of market growth, iii) competition, iv) state regulations, v) market profit, vi) technological development, vii) barriers to entry and exit, viii) capital intensity and ix) seasonality. All evaluated factors were adopted from Blažková (2007) and considered by selected experts from the forestry sector.

The methodology for setting up of the GE matrix consisted of (Horáková 2003; Blažková 2007):

a) the identification of factors for individual dimensions (axis $\mathrm{x}, \mathrm{y}$ ),

b) defining the selected factors,

c) ranking the wages of each factor by selected six experts in the given field. The individual wages were afterwards averaged by weighted arithmetical average,

- the wages presented the significance of individual factors which sum equals one (1)

- factor importance - the current state of each factor or the dependency level on given category of selected factor was rated by enterprise management, the ratings were in range of 1 to 5 (1 - unattractive, 5 - very attractive).

- final value of the factor - multiplying the wages with the ratings presented the final value for each factor.

d) finding the values of both dimensions (axis $x, y$ ) - presented the sum of the total values of factors by individual product types - roundwood assortments,

e) placing the (SBU) units into the portfolio matrix by bubble diagram in Excel,

f) displaying the range of the circles (bubbles) which were equivalent to the markets size of individual products (SBU) and

g) proposing the marketing strategy for each product (SBU) in the portfolio matrix.

The interpretation of the GE matrix by Blažková (2007) was used to examine the product portfolio. Following zonation into the nine fields or three zones was applied:

1. Top left - strategic profitable position of a products or services (SBU) in which the enterprise should invest and support their growth. It presents the strong advantages for the company. Sometimes it is called as a "green zone".

2. Diagonal - middle advantage strategic position of products or services (SBU). It is necessary to consider into which field to invest. This area of matrix is also termed as the "yellow zone".

3. Right down - unattractive position of the SBU. The enterprise must decide how it evaluates the individual fields of business or it rejects them. This zone is also called the "red zone".

Splitting the GE matrix into the equal nine fields required to fractionate both axis $(\mathrm{x}, \mathrm{y})$ into the three identical parts according to theoretical framework (Baran 2007). The range of each axis was given by the evaluation scale of identified factors from 1 - unattractive to 5 - very attractive. Therefore, the final range of each field in the matrix had the value of 1.33 .

\subsection{ABC analysis}

Also known as the analysis of the turnover structure shows the share of individual products, services or customers on the total turnover in terms of revenues. The results of the analysis provide the information about the turnover concentration and remind on the very strong dependence on several products, services or customers. 
The revenues of the individual products or services were counted by following formula:

$$
R_{i}=D_{i} \times P_{i}
$$

where

$R_{i}-$ total revenues of the i-product,

$D_{i}$ - deliveries of the i-product and

$P_{i}$ - price of the i-product.

Total revenues were calculated as:

$$
R=\sum_{i=1}^{k} R_{i}
$$

where

$R$ means the total revenues from all products,

$k$ is the number of produced products and

$R_{i}$ are the revenues of the i-product.

Within the $\mathrm{ABC}$ analysis, the individual roundwood assortments were categorized into the three groups according to their relative share on total revenues (Šulek 2004; Greppel et al. 2009):

- A group: roundwood assortments of the III. qualitative class (saw logs)

- B group: pulpwood and other industrial wood assortments of the $V$. qualitative class

- C group: assortments of the I., II. qualitative class (veneer, plywood) and fire-wood

In this case, the relative number of individual products (axis $\mathrm{x}$ ) came out from the total number of roundwood assortments (5). Therefore, the A and B group had at one fifth $(20 \%)$ products and $C$ group at three fifths (60\%).

\section{Results}

The management of forest enterprise identified by SWOT analysis the strengths, weaknesses, opportunities and threats of the roundwood assortments portfolio as follows (Table 1).

The prevailing strengths over the weaknesses (axis $x=22)$ and threats over the opportunities (axis $y=-13$ ) are the findings of the evaluation of individual indicators (Fig. 1). The diversification strategy is the recommen- dation for the given type of the product portfolio in the certain market place.

The reference of the proposed strategy is to decrease the impact of prevailing external threats on the selected product portfolio. Therefore, it is necessary to e.g.: i) substitute the indigenous species by species with skills to master current changing climate regarding the locality conditions, ii) adapt the silvicultural and exploitation processes to changing climate conditions, iii) adjust the share of own harvesting and transport facilities for necessity of prompt reaction on processing wood of gale-disaster areas, iv) optimize the portfolio of roundwood purchasers regarding the contracts length, price of roundwood assortments, product structure, etc.

The marketing strategy proposal is very narrow linked to the results of the SWOT, Threat and Opportunity matrices (Fig. $2-4$ ). Figure 2 shows, that most of the indicators are the strengths with the high seriousness what is the baseline for achieving the company's profit or maintenance the market position. Therefore, the recommendation is to focus on these indicators (see Table 1) and to keep their position with the correct managerial approaches.

Coming from the comparison of the threat and opportunity matrices (Fig. $3-4$ ), the prevalence of threats is evident. Therefore, suggested marketing strategy is to diversify the product portfolio. However, the best part of threats are indicators with less seriousness. Even thought, the probability of their occurrence needs to be spotted. In the present time, the indicator of invasive tree species (5) was considered as the less significant and the most substantial was the threat by bark-beetle (7) for chosen forest enterprise.

The BCG matrix at the company level reflects the situation on the domestic market with the roundwood assortments in the given period (2016 - 2017). It shows the balance rate of products in the company portfolio as well as its marketing strategy. The main pillar of the investigated product portfolio are coniferous and broadleaf assortments of III. qualitative class and broadleaf pulpwood (positions of cash cows and stars in the Fig. 5).

Table 1. SWOT indicators of the product portfolio.

\begin{tabular}{ll}
\hline \multicolumn{1}{c}{ Strengths } & \multicolumn{1}{c}{ Weaknesses } \\
\hline 1. quality of roundwood processing & 6. lower price of roundwood assortments comparing with the neighbouring countries \\
2. amount of roundwood assortments & 7. price competition among the roundwood assortments within the product portfolio \\
3. roundwood availability & 8. degree of processed roundwood into the assortments (question of added value) \\
4. guarantee of roundwood suppliers & \\
5. market share of roundwood assortments & \\
\hline \multicolumn{1}{c}{ Opportunities } & \\
\hline $\begin{array}{l}\text { 1. subventions for forest machinery revitalisation } \\
\text { 2. increasing demand on wood as a building and }\end{array}$ & 5. invasive tree species \\
interior material & 6. political influence \\
3. bioeconomy (green energy) & 7. bark-beetle \\
4. pricing regulations of forest ecosystem services & 9. gradation of wild animals \\
& 10. endangered tree species (spruce, fir, beech, oak, hornbeam) \\
& 11. increasing area of protected areas \\
& 12. strategy of the environmental policy of the Slovak Republic till 2030 \\
& 13. adverse development of the wood-processing and furniture industry \\
\hline
\end{tabular}




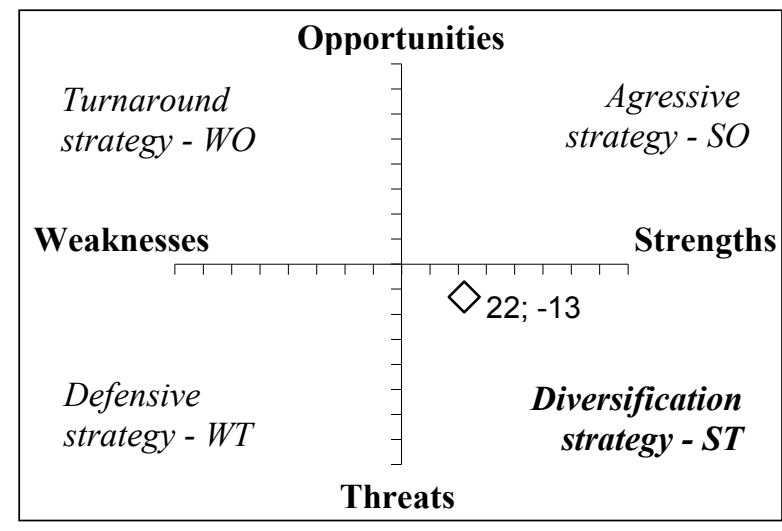

Fig. 1. Proposal of the marketing strategy.

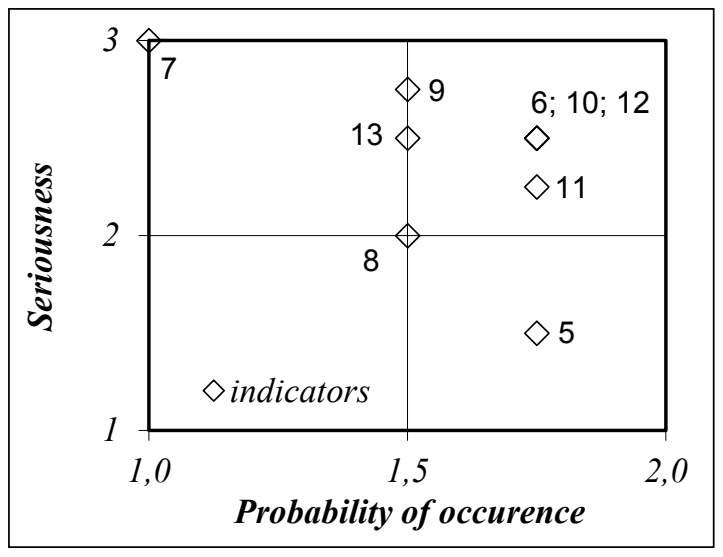

Fig. 3. Threat matrix.

These SBUs present $86 \%$ of total revenues coming from the sale of roundwood. This state confirms the prevalent demand on roundwood for production of sawn timber and pulp and paper on domestic market. From the pure economic viewpoint, other products (roundwood assortments positioned in the field of question marks and dogs) are unattractive SBUs according to their total amount and relative share on revenues, and growth index (assortments of I. II. qualitative class and fire-wood). Despite of the position of coniferous pulpwood in the matrix (dogs), it is traded together with the broadleaf pulpwood resulting from the business contracts with the dominant purchaser on the market. Therefore, it cannot be considered as unattractive.

In generally, seeing the particularity of roundwood assortments production in the forest sector, it is impossible that some of these products will be rejected from the portfolio or they would be not produced. Thus, the unattractive assortments used to be a part of the aggregated wood assortments, what is the case of I. II. qualitative class as a part of the III. class and pulpwood as part of the fire-wood by heat production. Additionally, assortments of the I. II. class like resonance wood, wood with specific structure etc. are usually traded by auction sale.

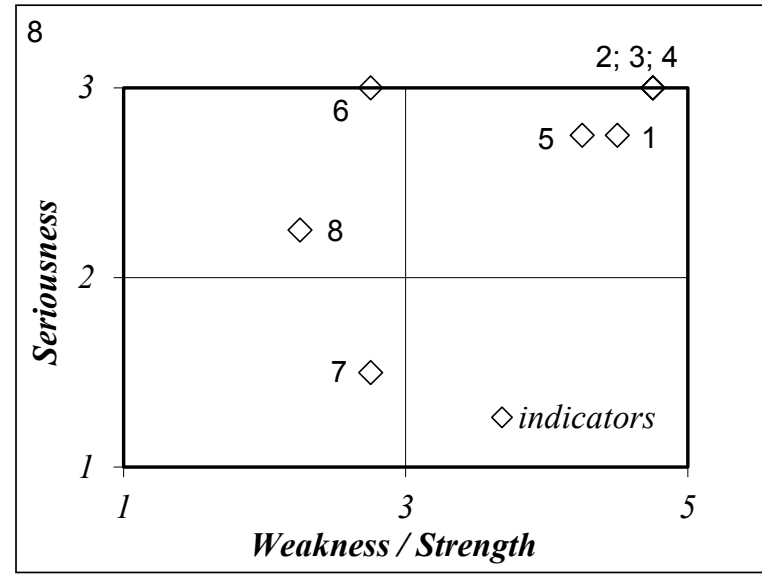

Fig. 2. SWOT matrix.

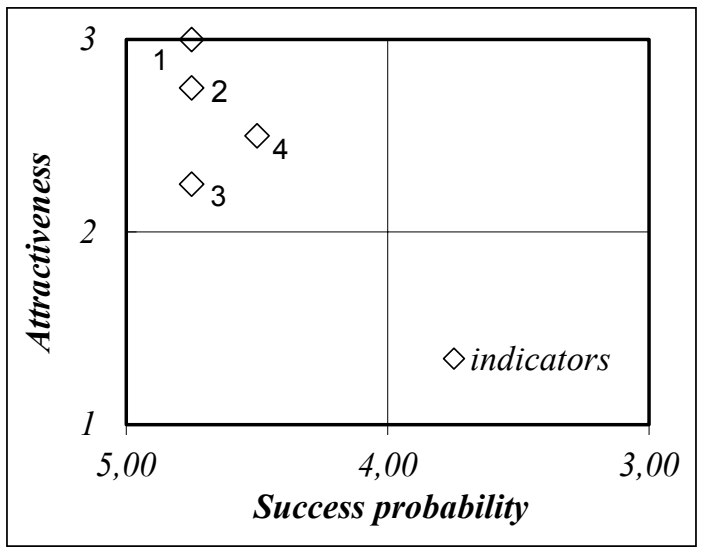

Fig. 4. Opportunity matrix.

The results evaluation of the product portfolio by GE matrix (Fig. 6) shows similar findings in comparison with BCG matrix. The assortments of the III. qualitative class have the highest rate of the competitive position and market attractiveness where broadleaves reach a bit higher market share with $2.79 \%$ as the coniferous with $2.01 \%$. They are situated in so called "green zone", the coniferous partly also in diagonal of the portfolio. However, these present the highest amount of revenues in the product portfolio. The broadleaf (with the market share of $1.71 \%$ ) and coniferous (1.44\% of market share) pulpwood is placed in so called "yellow zone", in the diagonal of the product portfolio. So, they are a little bit less attractive but still the most important for pulp and paper industry. The last portfolio products as assortments of fire-wood and I. II. qualitative class are in the "red zone" of the matrix. The biggest market share has the coniferous fire-wood with $2.48 \%$. The market share presents the product share from the company portfolio on the market capacity which is the sum of all realized revenues by state and non-state forest enterprises. However, the results and recommendation lead to same findings as by the BCG matrix. Despite of their position in the red zone, it is impossible not to produce them. 


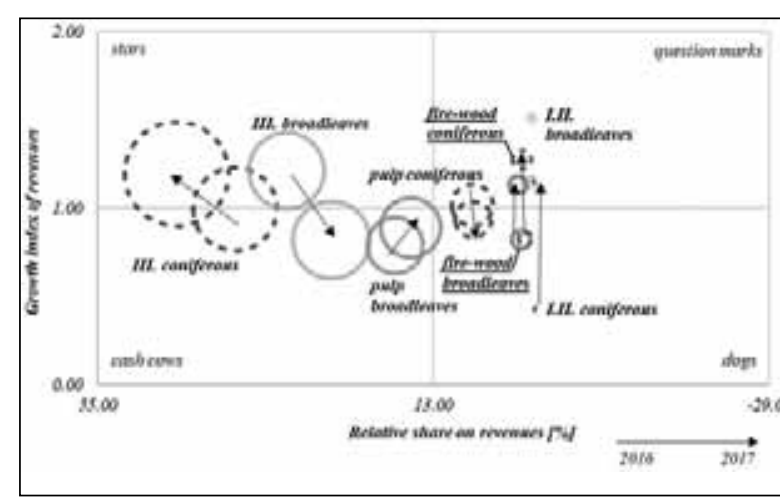

Fig. 5. BCG matrix of the roundwood assortments portfolio in the period 2016-2017.

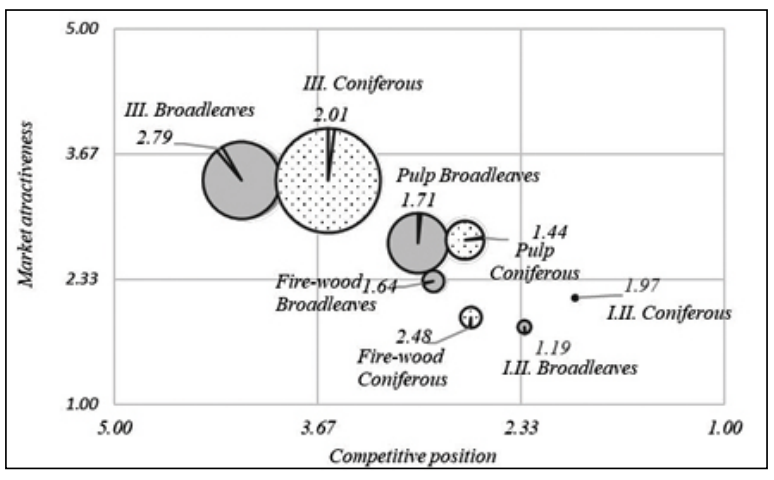

Fig. 6. GE matrix of the roundwood assortments portfolio in 2017.

The results of the $\mathrm{ABC}$ analysis (Fig. 7) point out that forest enterprise should pay the greatest attention to the A group of wood assortments (III. qualitative class of saw $\operatorname{logs})$. This group reaches the highest amount of turnover by number of $20 \%$ products by both wood species (81.40\%; 57.99\%) in investigated year 2017.

This score confirms the Pareto rule especially by coniferous roundwood portfolio. Another $20 \%$ of products (B group) present the share of $14.71 \%$ by coniferous and $35.66 \%$ by broadleaf pulpwood. The $C$ group despite of $60 \%$ product count reaches the rate only between 4 $6 \%$ share by coniferous and broadleaf wood assortments.

It results from the used decision-making models that chosen forest enterprise should furthest focus on the pro-

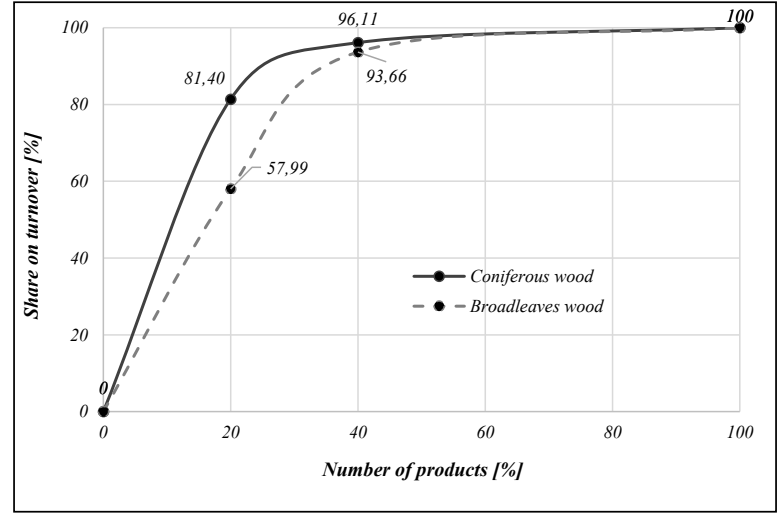

Fig. 7. ABC analysis (the curve of turnover concentration) of the roundwood assortments, 2017.

duction and sale of roundwood assortments within the III. qualitative class and pulpwood. It will be depending on several factors, for instance: i) the growing stock of individual assortments in the forest stand, ii) share of demanding wood species as e.g. spruce, beech, oak in the given qualitative classes, iii) economic and technical availability of roundwood assortments in the forest stand, iv) derived demand from wood-processing, paper and pulp, and furniture industry on roundwood assortments and v) cost and price range of roundwood assortments, etc.

Following the application of the decision-making models in practice, their advantages and disadvantages were evaluated and compared with the viewpoint of the forest enterprise (see Table 2). Within the outcomes from individual decision-making models, it can be stated that they represent a compact view about the product portfolio in the selected forest enterprise. They are a remarkable tool for decision-making of the forest enterprise management.

However, they require to know the production process and character of products. It helps to increase the quality of the results interpretation which can be otherwise very misleading. Each model brings its viewpoint or certain added value into the managing process. At the same time, models dispose with the similar information, which means that their results should not be contradict but complement.

Table 2. Comparison of the selected marketing decision-making models.

\begin{tabular}{|c|c|c|c|}
\hline \multirow{2}{*}{ Decision-making model } & \multicolumn{2}{|c|}{ The viewpoint of the technical use } & \multirow{2}{*}{ The viewpoint of the forest enterprise } \\
\hline & Advantages & Disadvantages & \\
\hline SWOT analysis & $\begin{array}{l}\text { consideration of key company priorities; } \\
\text { enables organization to set achievable goals, } \\
\text { objectives, or strategy }\end{array}$ & $\begin{array}{l}\text { snapshot of the company at a particular moment } \\
\text { in time; easy to mislead by identifying the SWOT } \\
\text { indicators }\end{array}$ & $\begin{array}{l}\text { handy tool for the prompt overview of the cur- } \\
\text { rent situation in the forest enterprise; construc- } \\
\text { tion of other matrices considered as too difficult }\end{array}$ \\
\hline BCG matrix & $\begin{array}{l}\text { simple and complex interpretation of rela- } \\
\text { tions among SBUs in the portfolio; ability to } \\
\text { predict the future SBUs positions }\end{array}$ & $\begin{array}{l}\text { only two parameters are considered; unclear by } \\
\text { more SBUs and longer time period }\end{array}$ & $\begin{array}{l}\text { easy to use except the graphical output; shows } \\
\text { the strengths and weaknesses of the enterprise }\end{array}$ \\
\hline GE matrix & $\begin{array}{l}\text { deep screening of each SBU position; high } \\
\text { expressing power }\end{array}$ & $\begin{array}{l}\text { time-consuming; difficult to gain so many } \\
\text { information; only current positions of the SBUs } \\
\text { are captured }\end{array}$ & $\begin{array}{l}\text { difficult to realize in every day practice; demand- } \\
\text { ing on input data }\end{array}$ \\
\hline $\mathrm{ABC}$ analysis & synoptic and undemanding on processing & $\begin{array}{l}\text { not possible to estimate the future development; } \\
\text { lower expressing power }\end{array}$ & $\begin{array}{l}\text { simple illustration of wood assortments struc- } \\
\text { ture according to turnover concentration }\end{array}$ \\
\hline
\end{tabular}


The SWOT analysis is often used also by forest enterprise, but only for the first step of identifying the internal and external indicators. However, this approach minimizes its expressing power. Therefore, it is necessary to conduct this analysis till the end and elaborate all matrices to find out the proper portfolio strategy, company goals for near future.

The contribution of the BCG matrix is in possibility of comparing the SBUs positions in the time period. However, the practical experiences recommend displaying maximum of two or three years depending on number of products due to its limpidity. It is not demanding on input data. On the other hand, GE matrix disposes with the information about the market place, products share on the total market capacity, their attractivity what are the data more difficult to obtain. They require also increased level of objectivity. However, they have excellent expressing power. The contribution of the $\mathrm{ABC}$ analysis is in the clustering products into the groups according selected code system. The effect of this approach is in finding of common and different product characters in portfolio. It is important that the clustering rules should underlie the logic, they should have correctly defined boundaries and they must be objective. For clustering codes are usually used following economic indicators, for instance: share on revenues, turnover, market share, the amount of sold products, etc.

The management of forest enterprise looks for the ratio of easiest application versus expressing power in the given supporting methods of decision-making and managing of the product portfolio. Therefore, the SWOT and $A B C$ analysis were accepted by forest enterprise as the most applicable methods or decision-making models.

\section{Discussion}

The case study results emphasize the possibilities of the combination of selected decision-making models within the marketing management in forestry practices. They build together such a mosaic and supporting tool for the decision-making process. It is necessary to stress out that these models were applied on the forest enterprise what represents a significant particularity within the interpretation of the research outcomes as well as the proposal of the recommendations. Regarding the chosen enterprise, it is a company managing primary the production function of the forests with the aim of its enhancement and encashment (generating the economic profit). Besides the optimization of the product portfolio, the use of these models must bring also the balance between both major targets of the enterprise.

Despite of the product portfolio belonging under the one enterprise, the products compete to each other in some cases inside of the portfolio. It is the example of pulpwood with the fire-wood. Their price levels latent compete (coniferous $21-27 € \mathrm{~m}^{-3}$, broadleaves 35 -
$39 € \mathrm{~m}^{-3}$ ) and so confirm this situation reflecting the market environment (Ministry of Agriculture and Rural Development of the Slovak Republic 2018). The increasing demand on fire-wood, or forest chips raised its price on the level of pulpwood what induced this competition also within the product portfolio in the last years. Some heating plants in term of fuel source availability and its price acceded to using also more valuable assortments as the pulpwood or assortments of III. qualitative class for heat production as the consequence. Behind this state was the binding target to increase the share of energy from renewable sources in final consumption of energy and hereby the strong support of green energy by state government in form of high feed-in tariffs (Commission of the European Communities 2008).

This adjustment of the green energy support incurred deformation also on the market with roundwood assortments. Therefore, there is a trend to decrease the feed-in tariffs or change into the feed-in premium, however, not in combined production of electricity and heat (309/2018 Z.z.). Despite of the boom in demand on energywood, the production of fire-wood as well as forest chips is ineffective for the chosen state forest enterprise. The fire-wood from thinning is sold to the locals for symbolic price or it is outsourced for forest chips production right next to the forest stand. In general, it depends on availability of wood material (forest road network, the level of forest stand access) and its concentration in the given locality.

Practical application of marketing decision-making models on the forest enterprise has its own particularities. There are several reasons e.g. (Brunette et al. 2015; Rymanov 2017): i) long production (rotation) period, ii) increasing occurrence of natural hazards, iii) wood processing technology, iv) differential land rent, etc. In this case study, the recommendation of marketing approach for managing the forest enterprise is to focus on the pillars of the product portfolio and to develop them. Concretely, it is concerned of increase roundwood assortments whereas III. qualitative class is the most treasured assortment regarding the ratio of its price and available amount on the market. Because there is a very few processing companies of I. and II. qualitative class (mainly for broadleaves processing, shortage of veneer mills, furniture companies), it is very implausible that forest enterprise could place a huge amount of these assortments on the domestic market (Paluš et al. 2015). One of the options is to export these assortments with the possibility of better economic assessment. Hence, the reference is to apply the diversification strategy for sales management. The next recommendation is not to break with the manipulation of the whole trunk length on individual assortments even by the forest stand. The forest enterprise loses the added value with this approach. Further, it is necessary to provide some own harvesting activities with own vehicles in comparing with outsourced force on the forest enterprise. The reasons behind are several due to the continuous processing of roundwood and its 
deliveries on the market, for instance: i) unreliability from one of the contractors, or ii) occurrence of accidental felling where by long public tenders for contractor the forest enterprise often loses profits (Paluš et al. 2011).

It is necessary to put the attention on the oversize product portfolio with the III. class assortments mainly coniferous. It is the effect of the forest management in Europe initiated by demand on economic effective wood species (spruce) from the $19^{\text {th }}$ century to the end of the first half of $20^{\text {th }}$ century. This approach lead to weak biodiversity of the local ecosystem. However, this state is nowadays by bark beetle calamity, climate change, considerably risky. Therefore, it is essential to substitute e.g. spruce (Table 1) by natural wood species like beech or fir (Carpathian mixture) in the given locations and gradually increase the share of mixed forest as well as the biodiversity.

The methodological reference for chosen forest enterprise is to supplement the $\mathrm{ABC}$ analysis by the analysis of the contribution to the fixed costs and so to increase its expressing power. Then, it will be necessary to account the structure of individual costs items for each roundwood assortment. The reason is that although strong products with the biggest share on the total sales need not to have a marked profit, or they can be even loss (Kádárová et al. 2015).

Based on the experiences with the application of the given marketing decision-making models into the praxis we can state following conclusions. By using the decision-making models, the scope of the market size depends on the size of the surveyed enterprise, type of the sector related to the examined company, character of the offered product or service, type of the target customers as well as available data (Evans \& Berman 1990). In the most cases, the marketing decision-making models are used at the regional or national level. However, concerning the transnational corporations disposing with enough data quantity (Baum 2012), they keep under review the positions of their subsidiaries on the global level, or in individual world regions (e.g. EU, Asia, North America etc.).

Chosen decision-making models serve mostly for the proposals of the managerial solutions in the short-term perspective for one or maximum two years, as well as within the operative planning. They are only supporting methods or approaches for the strategic decisions. They follow the actual situation on the markets and in the company portfolio. On the other hand, they are not the regular tools for the predictions. Their application for the goods of the commodity markets (behave on the principle of the derived demand) needs a precise interpretation of the results due to a lot of specifics coming from the character of the given markets (Kotler \& Keller 2015). However, within the marketing management of the forest enterprises portfolio the use of these models into praxis is an innovative approach of the forest resources management. It increases the competitiveness of forest enterprises, and their resistance against market changes. It optimizes their company portfolio and supports the quality of decision-making (Hansen \& Juslin 2011).

\section{Conclusion}

In consequence of the conducted case study, marketing management of the forest products portfolio is necessary. The decision-making process requests the combination of several viewpoints. The methods of marketing decision-making models can be applied in managing of forest enterprise and they are a great contribution. However, the important are the experiences, and knowledge of the marketer or manager for the correct interpretation of the results by individual matrices.

From the results, the forest enterprise is focused on the production of III. qualitative class of roundwood assortments (broadleaves and coniferous) as well as broadleaf pulpwood. This state outcomes from the condition of the forest land reserves where the forest enterprise operates as well as from the structure and current situation on the wood-processing, pulp and paper and furniture industry, also energy policy at the national and at the EU level.

\section{Acknowledgment}

The author is grateful for the financial support of the two projects at the Slovak Research and Development Agency (APVV-15-0715), (APVV-17-0232) and APVV-18-0520.

\section{References}

Baran, B. S., 2007: Die 9-Felder Matrix von McKinsey. Die 4-Felder Matrix der BCG (German Edition), GRIN Verlag, $24 \mathrm{p}$.

Baum, M., 2012: Strategic Management in a Global Context impact of the downturn: Examination and evaluation of the global impact of the downturn on the automotive industry and how the industries have reacted, Kindle Edition, GRIN Verlag, 54 p.

Blažková, M., 2007: Marketingové rízení a plánovaní pro malé a střední firmy. Praha, Grada Publishing, 280p.

Brodrechtova, Y., 2008: Determinants of export marketing strategies of forest products companies in the context of transition - The case of Slovakia. Forest Policy and Economics, 10:450-459.

Brunette, M., Holecy, J., Sedliak, M., Tuček, J., Hanewinkel, M., 2015: An actuarial model of forest insurance against multiple natural hazards in fir (Abies alba Mill.) stands in Slovakia. Forest Policy and Economics, 55:46-57.

Cooper, R. J., 1990: Marketing and international trade, Course notes for M.Sc. forest industries technology. SAFS UCNW, Bangor, UK 
Elyakime, B., Cabanettes, A., 2009: How to improve the marketing of timber in France? Forest Policy and Economics, 11:169-173.

Evans, J., Berman, B., 1990: Marketing. New York: Macmillan Publishing Company, $453 \mathrm{p}$.

FAO, 2018: The State of the World's Forests 2018 Forest pathways to sustainable development. Rome, $118 \mathrm{p}$.

Greppel, E., Paluš, H., Chudovský, D., Šulek, R., 2009: Zhodnotenie drevnej hmoty a marketingové riadenie. Zvolen, Národné lesnícke centrum, 148 p.

Halaj, D., Sedliačiková, M., Denisa, M., 2018: Customer behavior on the Slovakian roundwood market: a case study. BioResources, 13:6003-6020.

Haltofová, P., Štěpánková, P., 2014: An Application of the Boston Matrix within Financial Analysis of NGOs. Procedia - Social and Behavioral Sciences, 147:56-63.

Hansen, E., Juslin, H., 2011: Strategic marketing in the global Forest industries, second edition. Oregon State University, Corvallis, OR, USA, $607 \mathrm{p}$.

Herrera, F. F., 2018: Ecotechnological solutions to satisfy current demands of forest products, a glance beyond the trees. Forest Policy and Economics, 94:27-31.

Horáková, H., 2003: Strategický marketing. Praha: Grada Publishing, 204 p.

Huber, P., Hujala, T., Kurttila, M., Wolfslehner, B., Vacik, H., 2017: Application of multi criteria analysis methods for a participatory assessment of non-wood forest products in two European case studies, Forest Policy and Economics.

Chen, Y., Wu, D., Sun, J., Wang, F., Jiao, W., 2015: Design and Implementation of a Scientific Research Funds Analysis Model Based on Boston Matrix. Procedia Computer Science, 55:953-959.

Chirinko, R., S., Mallick, D., 2011: The elasticity of derived demand, factor substitution, and product demand: Corrections to Hicks' formula and Marshall's Four Rules. Labour Economics, 18:708-711.

Commission of the European Communities, 2008: Proposal for a Directive of the European Parliament and of the Council on the promotion of the use of energy from renewable sources 2008/0016 (COD), $61 \mathrm{p}$.

Jacobs, F. R., Berry, W. L., Whybark, D. C., Vollmann, T. E., 2010: Manufacturing Planning and Control for Supply Chain Management. The McGraw-Hill/ Irwin Series Operations and Decision Sciences, 6th Edition, $496 \mathrm{p}$.

Jochem, D., Janzen, N., Weimar, H., 2016: Estimation of own and cross price elasticities of demand for wood-based products and associated substitutes in the German construction sector. Journal of Cleaner Production, 137:1216-1227.

Kajanus, M., Leskinen, P., Kurttila, M., Kangas, J., 2012: Making use of MCDS methods in SWOT analysis Lessons learnt in strategic natural resources management. Forest Policy and Economics, 20:1-9.
Kaputa, V., Paluš, H., Vlosky, R. P., 2016: Barriers for wood processing companies to enter foreign markets: a case study in Slovakia. European journal of wood and wood products, 1:109-122.

Kádárová, J., Teplická, K., Durkáčová, M., Vida, M., 2015: Target Costing Calculation and Economic Gain for Companies. Procedia Economics and Finance, 23:1195-1200.

Kim, T. J., Wear, D. N., Coulston, J., Li, R., 2018: Forest land use responses to wood product markets. Forest Policy and Economics, 93:45-52.

Knauf, M., 2015: An Analysis of Wood Market Balance Modeling in Germany. Forest Policy and Economics, p. 319-326.

Kotler, P., Keller, K. L., 2015: Marketing Management. Student Value Edition (15th Edition), Pearson Publisher, $832 \mathrm{p}$.

Lovrić, M., Da Re, R., Vidale, E., Pettenella, D., Mavsar, R., 2018: Social network analysis as a tool for the analysis of international trade of wood and nonwood forest products. Forest Policy and Economics, 86:45-66.

Ludvig, A., Tahvanainen, V., Dickson, A., Evard, C., Kurttila, M., Cosovic, M., 2016: The practice of entrepreneurship in the non-wood forest products sector: Support for innovation on private forest land. Forest Policy and Economics, 66:31-37.

Ministry of Agriculture and Rural Development of the Slovak Republic, 2018: Správa o lesnom hospodárstve v Slovenskej republike za rok 2017 - Zelená správa, Bratislava, $65 \mathrm{p}$.

Ministry of the economy of the Slovak Republic, 2018: Novela zákona o podpore obnovitelných zdrojov energií (OZE) a vysoko účinnej kombinovanej výroby (KVET), 309/2018 Z.z.

Meffert, H., Burmann, Ch., Kirchgeorg, M., 2014: Marketing: Grundlagen marktorientierter Unternehmensführung Konzepte - Instrumente - Praxisbeispiele (German Edition). Springer Gabler; 12th Edition, 886 p.

Neis, F. A., Costa, F., Araújo, A. T., Fett, J. P., FettNeto, A. G., 2019: Multiple industrial uses of nonwood pine products. Industrial Crops and Products, 130:248-258.

Ok, K., 2005: Idea marketing in forestry: some implications from the Turkish forestry experience. Forest Policy and Economics, 7:493-500.

Paluš, H., Kaputa, V., Parobek, J., Šupín, M., Halaj, D., Šulek, R., Fodrek, L., 2011: Trh s lesníckymi službami. Zvolen, Technická univerzita vo Zvolene, $45 \mathrm{p}$.

Paluš, H., Parobek, J. Dzian, M., Šupín, M., 2018: Determinants of sawnwood consumption in Slovakia. BioResources, 2:3615-3626.

Paluš, H., Parobek, J., Liker, B., 2015: Trade performance and competitiveness of the Slovak wood processing industry within the Visegrad group countries. Drvna Industrija: znanstveni časopis za pitanja drvne technologije, p. 195-203. 
Parobek, J., Paluš, H., Kaputa, V., Šupín, M., 2014: Analysis of wood flows in Slovakia. BioResources, 4:6453-6462.

Rönnqvist, M., D‘Amours, S., Carle, M.-A., Azouzi, R., 2018: Timber selling policies using bundle-based auction: The case of public forests in Québec. Forest Policy and Economics, 96:9-18.

Rymanov, A., 2017: Differential land rent and agricultural taxation. Agricultural Economics - Czech, 63:421-429.

Samejima, M., Shimizu, Y., Akiyoshi, M., Komoda, N., 2006: SWOT analysis support tool for verification of business strategy. IEEE international conference on computational cybernetics, IEEE, p. 1-4.

Sarvašová, Z., Dobšinská, Z., 2016: Provision of ecosystem services in mountain forests - case study of experts 'and stakeholders 'perceptions from Slovakia. Journal of forest science, 8:380-387.

Sarvašová, Z., Dobšinská, Z., Šálka, J., 2014: Public participation in sustainable forestry: the case of forest planning in Slovakia. iForest - biogeosciences and forestry, 6:414-422.
Seggie, S. H., Cavusgil, E., Phelan, S. E., 2007: Measurement of return on marketing investment: A conceptual framework and the future of marketing metrics. Industrial Marketing Management, 36:834-841.

Slávik, Š., 2005: Strategický manažment. Sprint, 403 p. Šišák, L., Riedl, M., Dudik, R., 2016: Non-market nontimber forest products in the Czech Republic - Their socio-economic effects and trends in forest land use. Land Use Policy, 50:390-398.

Šulek, R., 2004: Marketingové riadenie lesných podnikov. Vedecké štúdie, 5/2004/A. Zvolen, TU Zvolen, $59 \mathrm{p}$.

Torquati, B., Scarpa, R., Petrosillo, I., Ligonzo, M. G., Paffarini, Ch., 2018: Chapter 10: How Can Consumer Science Help Firms Transform Their Dog (BCG Matrix) Products Into Profitable Products? Case Studies in the Traditional Food Sector, p. 255-279. Wild, T., 2017: Best Practice in Inventory Management. Routledge, 3 edition, 294 p. 